\title{
Molecular Characterization of Natural Fungal Flora in Black Olives: From Field to Table
}

\author{
Nisa Ozsoy ${ }^{1}$, Hilal Ozkilinc ${ }^{2 *}$, Cigdem Uysal Pala ${ }^{1}$ \\ ${ }^{I}$ Food Engineering Department, Engineering Faculty, Çanakkale Onsekiz Mart University, 17100 Çanakkale, Turkey \\ ${ }^{2}$ Department of Molecular Biology\&Genetics, Faculty of Arts and Sciences, Çanakkale Onsekiz Mart University, 17100 Çanakkale, Turkey
}

\section{A R T I C LE IN F O}

\section{Research Article}

Received 31 March 2017

Accepted 29 June 2017

Keywords:

Olive

Fungus

Molecular identification

Beta-tubulin

Fermentation process

*Corresponding Author:

E-mail: hilalozkilinc@ @omu.edu.tr
A B S T R A C T

In this study, molecular markers were used to determine fungal flora in black olive fruits from field surveys to the table, following the fermentation process. Field samples were collected from different locations of Canakkale province, including Gokceada (Imbros), where organic farming is employed. Some of the fruits from field samples were used for black table olive production and then fungal flora was tracked during the fermentation process. Fungal isolation was also conducted on some commercial samples. Fifty seven isolates from field samples, 56 isolates from the fermentation process and 17 isolates from commercial products were obtained. Among these isolates, 41 Alternaria, 43 Penicillium, 19 Aspergillus, 8 Monascus and 19 other genera were determined using amplified sizes of the Beta-tubulin gene region. Species level identification was carried out based on sequences of Beta-tubulin amplicons, which provided accurate identification, especially where the genera were morphologically highly similar. The occurrence and prevalence of fungal species changed in fungal collections from the field to the fermentation process. While Alternaria alternata was common in field samples, they were absent during fermentation. Many of these identified species, such as Penicillium expansum, Aspergillus niger and Monascus pilosus, which are known as potential toxin producers such as aflatoxin, ochratoxin A and citrinin, were found both in natural and fermented samples, even at the end of the fermentation process. These results showed that some fungal species which survive on olives from the field to the table are potential toxin producers and can be successfully characterized by amplification and sequencing of Beta-tubulin gene.

DOI: https://doi.org/10.24925/turjaf.v5i8.944-949.1255

\section{Introduction}

Olive is the common name for the greenish fruits of the Oleaceae family. Olive is an important part of the Mediterranean diet, and defined as a functional food because of their antimicrobial, antimutagenic, anticarcinogenic and antioxidant properties (Sahin et al., 2010; Marsilio, 2001). They also differ from other fruits due to their high oil content and bitter taste which is mainly caused by oleuropein, a phenolic compound. Anthocyanins, flavanols, phenolic acid and phenolic alcohols are important phenolic compounds in olives (Baskou, 2015). These phenolic compounds play an important role in general antioxidant activity.

Olive is one of the most important agricultural products in Turkey with 1.73 million tons of olive production, and where 430,000 tons of these olives are used in the production of table olive (TUIK, 2016). Canakkale provides about $4.2 \%$ of total olive production in Turkey (TUIK, 2013). Table olive processing is carried out by small family companies in Canakkale (Ozkaya et al., 2010).
In Turkey, the most common process for black table olive is spontaneous fermentation. In this method, olive fruits are harvested when they have a black outer shell and a violet interior, then they are fermented in brine with a concentration of 6 to $10 \%$ salt (Aran, 2012). Fungal flora that form as a biofilm on the olive brine pool (called 'Kefeke' in Turkey), can occur in olives that are packaged or being prepared for packing. While Penicillium is the most common species, Aspergillus, Cladosporium, Ulocladium, Rhizopus, Alternaria and Paecilomyces are the other fungal species found in olives (Sahin and Korukoglu, 2000). The fungal flora may come from the field before the fermentation process, alive and reproduce during fermentation or appear due contamination during the process, and some of the fungal species may produce mycotoxins, which are harmful for human consumption.

Molecular techniques provide faster and more accurate diagnosis of fungal species than traditional approaches. For example, yeast in table olives have been identified by molecular methods (Arroyo-López et al., 
2006). Molecular methods are used for the identification and diversity of fungal flora in many foods such as coffee beans, maize grains, grapes (Magnani et al., 2005; Lumi et al., 2015; Wang et al., 2015). The ribosomal DNA region, and some protein-coding regions such as calmodulin, $\beta$-tubulin and elongation factors are commonly used in fungal systematics (Carbone and Kohn, 1999; Russell and Peterson, 2006; Gonvances et al., 2012). Primer pair developed for $\beta$-tubulin region could widely be used to detect different fungal species (Glass and Donaldon, 1995). In this study, fungal flora was characterized in black table olives from the field to the table using a molecular approach to observe diversity and changes in fungal species.

\section{Materials and Methods}

\section{Plant Material}

Olive fruits were collected from different locations of Canakkale province, including Gokceada, Ezine, Intepe, the city center of Canakkale and Assos in November of 2015 (Table 1). Healthy, physically injured excluding insect infested ones, diseased and moldy fruits were collected from both trees and ground. Sampling were done from 27 trees of olive cultivars Edremit and Ladolyes, and 7 wild olive trees (Table 1). Wild trees were not exposed to any cultivation practices except being used as rootstock. Fruit samples were categorized according to their collection source (state of health, from a tree or ground, from wild or cultivated trees, olive cultivars) to associate fungal isolates.

\section{Black Table Olive Production}

Fully mature black olives from Edremit cultivar were harvested from trees planted in the Ezine county of Canakkale and used for natural black table olive production. Lab-scale production $(n=4)$ was carried out in plastic containers $(10 \mathrm{~L})$, filled with $7 \mathrm{~kg}$ of olive fruits and $3 \mathrm{~L}$ of brine $(10 \% \mathrm{NaCl} \mathrm{w} / \mathrm{w})$. The containers were incubated for natural fermentation at room temperature. The brine was not replaced with a fresh solution during the fermentation process. Sampling was carried out during the fermentation process: on the first day to see what initially occurs, on the day 120 , which is when the biofilm begins to form and on the day 240, which is the end of the process. In addition, fermented fruit samples were obtained from five olive-producing commercial companies that produce table olive in Ezine/Canakkale.

\section{Fungal Isolations and DNA Extraction}

Surface sterilization of the fruit samples were carried out with $2.5 \%(\mathrm{w} / \mathrm{w})$ sodium hypochlorite $(\mathrm{NaOCl})$ for 3 min, and then rinsed three times with sterile distilled water and left to dry. After surface sterilization, healthy fruits were directly placed on Potato Dextrose Agar (PDA) (Merck, Germany). Fruits with disease, wounds or having naturally fungal hyphae before sterilization, were cut into small pieces and those parts were transferred to PDA Petri dishes and incubated under $12 \mathrm{~h}$ light and $12 \mathrm{~h}$ dark at room temperature for three to five days. Additionally, fungal isolations were performed from biofilm of fermented olive bottles. Sampling from biofilm was done at the end of the fourth and eighth months. Besides, biofilm sampling was taken from commercial olive-producing companies at the end of fermentation. Samples taken from the biofilm were transferred to a PDA medium and incubated at the same conditions stated above. All growing fungal samples from both fruit and biofilm sources were transferred to new PDA media, and single-spore isolations were done from pure cultures. Fungal cultures obtained from single spores were used in all analyses. Cultures from single-spore colonies were kept in sterile whatman no 1 paper at $-20^{\circ} \mathrm{C}$ for long-term storage Based on colony and spore morphologies, each isolate was evaluated morphologically, but molecular data was used for identification.

DNA was isolated from each fungal isolate obtained. Mycelia were grown in a Potato Dextrose broth (Merck, Germany) medium for five days in an orbital shaker at $150 \mathrm{rpm}$ at room temperature. Mycelia were harvested and lyophilized to use in DNA isolation. Total genomic DNA extractions were carried out using an i-genomic Plant DNA Extraction Kit (Intron Biotechnology, Korea) according to the manufacturer's instructions.

Table 1 Plant materials obtained from Canakkale in 2014.

\begin{tabular}{|c|c|c|c|c|c|c|c|}
\hline \multirow[b]{2}{*}{ Region } & \multicolumn{2}{|c|}{ Coordinates } & \multirow{2}{*}{$\begin{array}{l}\text { Altitude } \\
\text { (m) }\end{array}$} & \multicolumn{2}{|c|}{ Olive trees sampled } & \multirow{2}{*}{$\begin{array}{l}\text { Number of } \\
\text { fruits } \\
\text { collected }\end{array}$} & \multirow{2}{*}{$\begin{array}{c}\text { Number of } \\
\text { fungal isolates } \\
\text { obtained }\end{array}$} \\
\hline & Latitude & Longitude & & $\begin{array}{c}\text { Cultivar } \\
\text { type }\end{array}$ & $\begin{array}{l}\text { Number of } \\
\text { trees sampled }\end{array}$ & & \\
\hline Gokceada & $40^{\circ} 07^{\prime}$ & $25^{\circ} 44^{\prime}$ & 36 & $\begin{array}{c}\text { Edremit } \\
\text { Ladolyes } \\
\text { Wild } \\
\end{array}$ & $\begin{array}{l}4 \\
9 \\
2 \\
\end{array}$ & 20 & 15 \\
\hline Ezine & $39^{\circ} 46^{\prime}$ & $26^{\circ} 11^{\prime}$ & 12 & $\begin{array}{c}\text { Wild } \\
\text { Edremit }\end{array}$ & $\begin{array}{c}2 \\
10\end{array}$ & 28 & 23 \\
\hline Assos & $39^{\circ} 29^{\prime}$ & $26^{\circ} 19^{\prime}$ & $3-118$ & $\begin{array}{c}\text { Wild } \\
\text { Edremit }\end{array}$ & $\begin{array}{l}2 \\
4\end{array}$ & 16 & 12 \\
\hline $\begin{array}{l}\text { Canakkale } \\
\text { (around city } \\
\text { center area) }\end{array}$ & $40^{\circ} 07^{\prime}$ & $25^{\circ} 44^{\prime}$ & 86 & Wild & 1 & 6 & 7 \\
\hline
\end{tabular}




\section{Fungal Molecular Identification}

The partial region of Beta-tubulin ( $\beta$-tubulin) coding gene was used for molecular identifications. $\beta$-tubulin was amplified with primer pairs $\mathrm{Bt} 2 \mathrm{a}$ and $\mathrm{Bt} 2 \mathrm{~b}$ (Glass and Donaldson, 1995), respectively. A $25 \mu \mathrm{L}$ volume of PCR containing 1x PCR buffer (Invitrogen), $3 \mathrm{mM}$ of $\mathrm{MgCl}_{2}$ (Applied Biological Materials Inc., Canada), $2 \mathrm{mM}$ of each dNTP, $0.4 \mu \mathrm{M}$ of each primer, $1 \mathrm{U}$ of Taq polymerase (Promega, Madison, WI) and 10 to $15 \mathrm{ng}$ of DNA. The PCR conditions for the $\beta$-tubulin region were $95^{\circ} \mathrm{C}$ for $5 \mathrm{~min}, 45$ cycles at $95^{\circ} \mathrm{C}$ for $20 \mathrm{~s}, 55$ to $59^{\circ} \mathrm{C}$ for $30 \mathrm{~s}$, and $72^{\circ} \mathrm{C}$ for $30 \mathrm{~s}$, followed by a final step at $72^{\circ} \mathrm{C}$ for 5 min All PCR reactions were carried out in a thermal cycler Bio-Rad T100 (Bio-Rad, USA).

PCR products were visualized on $1.5 \%$ agarose gels dyed with $5 \mu \mathrm{L} / 100 \mathrm{~mL}$ of nucleic acid dye (SafeView, Applied Biological Materials Inc., Canada) and under UV light of a gel documentation system - Vilber Lourmat Quantum ST4 1100 (Vilber Lourmat, France). Some of the PCR products were sequenced in an ABI 3500xL Genetic Analyser (Applied Biosystems, MedSanTek, Istanbul, Turkey). Bioedit v7.0.53 for Windows software (Hall, 1999) was utilized to check and edit DNA sequences and, then, sequences were aligned using clustalW implemented in BioEdit software. Each sequence data was searched for similarities using BLASTn from the Basic Local Alignment Search Tool (http://blast.ncbi.nlm.nih.gov /Blast.cgi) (Altschul et al., 1990).

\section{Results and Discussion}

\section{Molecular Identifications}

A total of 130 fungal isolates were obtained in this study: 57 from field samples, 22 from the first day of table olive production, 17 isolates from the biofilm formation stage (day 120) during fermentation and 17 isolates from the final fermented product (day 240) before packaging (Table 2). Seventeen fungal isolates were obtained from the commercial product sampling at the end of fermentation (Table 2). $\beta$-tubulin amplification was successful in distinguishing different fungal genus even with size amplification on agarose gel: $400 \mathrm{bp}$ for Alternaria, $500 \mathrm{bp}$ for Penicillium and $600 \mathrm{bp}$ for Aspergillus (Figure 1). So, this region is suggested for rapid identification at genus level. Monascus produced $600 \mathrm{bp}$ product for Beta-tubulin, which is the same size produced from the Aspergillus genus. But, these two genus are easy to distinguish morphologically. Moreover, sequences of the $\beta$-tubulin region were resolved for species-level identification (Table 3). Sequencing was performed for 77 isolates within a total collection of 130 isolates. The sequences were compared with sequences recorded in the National Center for Biotechnology Information (NCBI) gene bank and the most closely related sequences were presented in Table 3. Among the species detected, $P$. expansum, A. niger, A. tubingensis and $M$. pilosus are known to be potential mycotoxin producers such as aflatoxin, ochratoxin A and citrinin. Thus, rapid and accurate identification of these fungi is important so that control strategies could be applied against to the fungal contaminations.

The fungal flora and frequency of the species differed between the field collection and the fermentation process (Table 2). $\beta$-tubulin sequence data was not able to resolve species-level identification for Alternaria. Morphologically, it belongs to small-spored Alternaria section and it is known that species-level identification for this group is highly challenging. We identified it as $A$. alternata, based on morphology and Endopolygalacturanase data from another study (Ozkilinc H., unpublished data).

\section{Fungal Flora from Field Survey}

Forty-two isolates from cultured olive trees, and 15 isolates from wild olive trees were obtained (Table 2). Among these isolates, forty-seven were isolated from olive fruits and ten from olive leaves. Fifteen Alternaria, four Penicillium and two Aspergillus fungi were isolated from damaged parts of the olive fruits. Alternaria causes pathogenic symptoms (Ozkilinc H.., unpublished data) and the pathogenicity of Alternaria in olives was shown in other studies (Piccolo et al., 2014). Penicillium and Aspergillus are not known as olive pathogens, but these fungi may colonize easily, especially in damaged tissues. By contrast, only four isolates of Penicillium and two isolates of Aspergillus were isolated from healthy olives, which indicates that some fungi may present without any sign. Even though Penicillium and Aspergillus do not cause disease on the fruit, they may potentially be dangerous due to being toxin-producers. In addition to these major fungal groups, some other species such as Fusarium, Cladosporium, Epicooccum, Phoma and Clonostachys were detected at a low frequency. Similar diversity of fungal species in olives in a natural environment has been reported in previous studies. Chliyeh et al. (2014) studied all the fungal species associated with olive trees in Morocco and reported that A. alternata was identified in ranges from 13 to $84.5 \%$ for all studied regions. In another study, fungi were isolated from sub-cortical brown streaking and from the cankers of wilted olive plants (Carlucci et al., 2013). The total isolation frequency of A. alternata, Aspergillus spp. and Penicillium spp. was reported as 3.3, 8.9 and $5.4 \%$, respectively (Carlucci et al., 2013). For example, $42 \%$ of the total isolates from olive trees were Alternaria, Penicillium and Fusarium were identified from olive trees in Portugal and the $42 \%$ of the total isolates was reported as Alternaria(Oliveira et al., 2012). Baffi et al. (2012) reported that Aspergillus and Penicillium species were major fungal genera in olive ecosystems such as olive fruits, olive pomace and olive paste. Al-Ameri et al., (2015) has isolated A. niger (13\% sample frequency) from olive fruit rot. Roussos et al. (2006) reported that Aspergillus and Penicillium were the dominant mold flora in olive oil production efforts in Morocco and that $A$. niger was the most widely distributed. Thus, the dominant species in this study are consistent with those isolated in previous studies. 
Table 2 Fungal species frequency from field to during table olive fermentation.

\begin{tabular}{|c|c|c|c|c|c|c|c|c|c|c|c|c|c|c|c|}
\hline \multirow{2}{*}{\multicolumn{3}{|c|}{ Source }} & \multicolumn{3}{|c|}{ ALT } & \multicolumn{4}{|c|}{ PEN } & \multicolumn{3}{|c|}{ ASP } & \multirow{2}{*}{$\begin{array}{r}M N \\
\text { SP11 }\end{array}$} & \multirow{2}{*}{$\mathrm{O}^{*}$} & \multirow{2}{*}{$\mathrm{T}$} \\
\hline & & & SP1 & SP2 & SP3 & SP4 & SP5 & SP6 & SP7 & SP8 & SP9 & SP10 & & & \\
\hline Field Sampling & \multicolumn{2}{|c|}{ Olive Fruits } & 35 & 3 & 1 & 1 & 1 & 1 & - & 1 & 3 & - & - & 10 & 57 \\
\hline \multirow{6}{*}{$\begin{array}{l}\text { Fermentation } \\
\text { process }\end{array}$} & Olive & LSP & 5 & 6 & 4 & - & - & - & - & 1 & 3 & - & 3 & 1 & \multirow{2}{*}{26} \\
\hline & Fruits & $\mathrm{C}$ & - & 1 & - & - & - & - & - & - & - & 1 & 1 & - & \\
\hline & \multirow{2}{*}{ Brine } & LSP & 1 & 7 & 2 & 2 & - & - & 2 & 1 & 2 & - & 1 & - & \multirow{2}{*}{24} \\
\hline & & $\mathrm{C}$ & - & & - & 1 & - & - & - & - & - & 3 & - & 3 & \\
\hline & Biofilm & LSP & - & 6 & 3 & - & - & - & - & 3 & - & - & 2 & 2 & 23 \\
\hline & (Kefeke) & $\mathrm{C}$ & - & 1 & 1 & - & - & - & - & - & - & 1 & 1 & 3 & 23 \\
\hline \multicolumn{3}{|c|}{ Total } & 41 & & & \multicolumn{2}{|c|}{43} & & & & 19 & & 8 & 19 & 130 \\
\hline
\end{tabular}

ALT: Alternaria, PEN: Penicillium, ASP: Aspergillus, MN: Monascus, O: Others, T: Total, LSP: Lab-scale production, C: Commercial, SP1: A. alternata, SP2: Penicillium spp., SP3: P. crustosum, SP4: P. roquefortii, SP5: P. brevicompactu, SP6: P. glabrum, SP7: P. expansum, SP8: Aspergillus spp., SP9: A. niger, SP10: A. tubingensis, SP11: M. pilosus, *Fusarium, Clodosporium Epicooccum, Phoma, Clonostachy.

Table 3 Fungal species identified based on partial sequence data of Beta-tubulin region.

\begin{tabular}{l|lccl}
\hline \multicolumn{1}{c|}{ Isolates } & \multicolumn{1}{c}{ Source } & SL & Identity $^{\mathrm{a}}$ & \multicolumn{1}{c}{ The best match reference $^{\mathrm{b}}$} \\
\hline A. alternata & Field sampling-olive fruit & 280 & $99 \%$ & KU512287.1- Alternaria alternata \\
$P$. crustosum & Day 1 of olive fermentation-olive fruit & 392 & $100 \%$ & FJ004401.1- Penicillium crustosum \\
$P$. glabrum & Field sampling-olive fruit & 353 & $99 \%$ & EU128585.1-Penicillium glabrum \\
P. roquefortii & Day 1 of olive fermentation -brine & 445 & $99 \%$ & AY674382.1-Penicillium roquefortii \\
$P$. expansum & Day 1 of olive fermentation -brine & 362 & $99 \%$ & LN896431.1- Penicillium expansum \\
$P$. brevicompactum & Field sampling-olive fruit & 264 & $99 \%$ & AY674436.1-Penicillium brevicompactum \\
A. niger & Field sampling-olive fruit & 535 & $100 \%$ & KC175288.1-Aspergillus niger \\
A. tubingensis & Commercial sampling & 447 & $99 \%$ & HQ632767.1-Aspergillus tubingensis \\
M. pilosus & Day 240 of olive fermentation/biofilm & 484 & $99 \%$ & AB607170.1-Monascus pilosus \\
\hline
\end{tabular}

${ }^{\mathrm{a}}$ Sequence similarity with one of the most related sequences from NCBI. ${ }^{\mathrm{b}}$ Genebank accession numbers with one of the most related sequences from NCBI-GeneBank, SL: Sequence length (bp)

Fungal Flora from the Table Olive Fermentation Process

Twenty-three isolates from olive fruits, seventeen isolates from brine and sixteen isolates from biofilm were obtained during the fermentation process (Table 2). While Alternaria was the most common fungus in field samples, it was not detected in fermented products. As an independent test, Alternaria, Penicillium and Aspergillus species (two isolates per genus) were inoculated into 100 $\mathrm{mL}$ of sterilized brine While Penicillium and Aspergillus grew successfully, Alternaria did not grow. High salt concentration or antioxidants, especially oleuropein, may inhibit Alternaria growth. But, these conditions do not seem to restrict reproduction of Aspergillus and Penicillium. A previous study showed that $\mathrm{KCl}$ and $\mathrm{NaCl}$ together with cassia oil have an antifungal effect on $A$. alternata isolates (Feng and Zheng, 2006). Moreover, antifungal effect of phenolic compounds in olive is also known (Pereira et al., 2007). It is thought that the antifungal properties of phenolic components are much more effective on Alternaria than the other fungi in this study. Thus Alternaria is mainly a problem as a disease agent for olives in a natural environment, but Aspergillus and Penicillium can be present from field to table. Hence, if toxin production occurs, it should be determined at which stage or under what conditions toxin production is favored.

The dominant mold flora during fermentation was Penicillium (49\%) and Aspergillus (20\%). P. crustosum (14\%) was the most common Penicillium species. Other species were $P$. roqueforti $(4 \%)$ and $P$. expansum $(2 \%)$, respectively. $P$. brevicompactum and $P$. galabrum were, however, not isolated during fermentation. Two species of Aspergillus (A.niger and A.tubingensis) was found at the same frequency (7\%). Similarly, Sahin and Korukoglu
(2000) reported that Penicillium is the dominant species in the brine of pickled food. In addition, $P$. roqueforti, $P$. brevicompactum and $P$. citrinum were isolated from naturally fermented black olives in previous studies from Turkey (Heperkan et al., 2006; Heperkan et al., 2013). P. expansum and $A$. niger species detected in the study have potential to produce mycotoxins such as ochratoxin A and citrinin. If these species produce toxins, it will result in a toxin contaminated final product. Adlouni et al. (2006) stated that aflatoxin, ochratoxin A and citrinin was found in some of the black table olive samples from retailer and supermarket. Ghitakou et al., (2006) reported aflatoxin B1 and ochratoxin A production by natural microflora and $A$. parasiticus in black and green olives of Greek origin. Our research will continue to determine whether this threat exists.

Commercial sampling was taken from five olive companies in the Canakkale area. The major mold flora was Penicillium, Aspergillus and Monascus. Additionally, P. crustosum, A. tubingensis and M. pilosus were the most common species. M. pilosus was $10 \%$ of all isolates. Many isolated $M$. pilosus was from olive fruits and biofilm. Fermented products from laboratory experiments and commercial sampling presented similar fungal flora, but in different numbers: the number of Monascus isolates were higher in commercial products compared to the samples taken from laboratory scale production. Some of the Monascus species such as M. purpureus and some $M$. pilosus are known as Mon $\mathrm{K}$ toxin producers ( $\mathrm{Su}$ et al., 2003; Hong et al., 2011). P. crustosum was reported as a major fungal species in commercial olive samples in Turkey and P. expansum and P.roqueforti were also reported from commercial olive products in previous similar studies (Tokusoglu et al., 2010). 


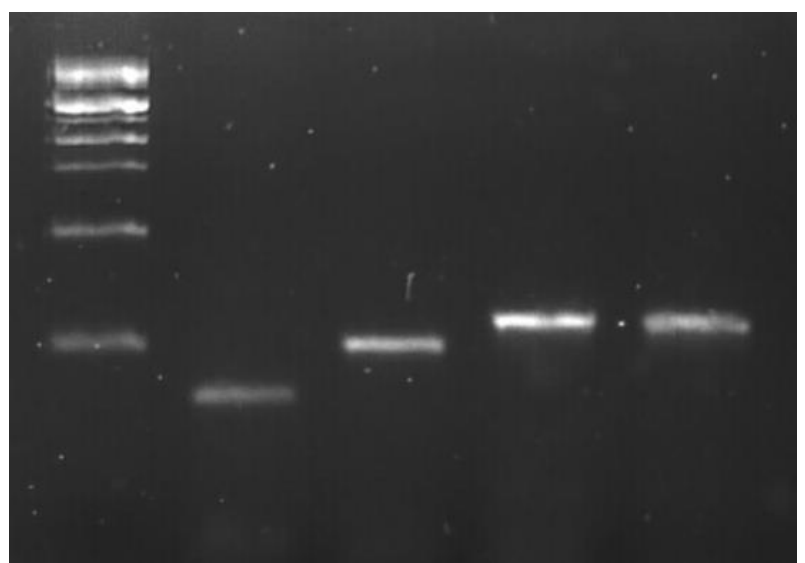

Fig. 1 Identification of Alternaria, Penicillium, Aspergillus and Monascus fungal genus by using amplification sizes of PCR with $\beta$-tubulin primers. The first line is DNA ladder (1 kb DNA ladder, Geneaid) and following lines for Alternaria ( 400 bp), Penicilium ( $\sim 500 \mathrm{bp})$, Aspergillus ( $\sim 500 \mathrm{bp})$, Monascus ( $\sim 60 \mathrm{bp})$, respectively.

\section{Conclusion}

Variety in fungal species on olives from field to table were shown in this study, and a fungal diagnosis was performed based on amplification and sequences of partial region of $\beta$-tubulin coding gene. The study showed that the amplification size of partial $\beta$-tubulin gene is very useful to discriminate between major fungal groups related to olive products at both a genus level and, with further sequencing information of $\beta$-tubulin, at a species level - except for Alternaria. While Alternaria poses a danger as a pathogen for fruit on trees, many species from Aspergillus and Penicillum are present in the product from field to table.Many of these species are known as mycotoxigenic species. Therefore, it is crucial to determine the conditions for toxin production by these species during this whole process.

\section{Acknowledgement}

This research was supported by Canakkale Onsekiz Mart University Research Funds (FDK-2015-453).

\section{References}

Adlouni CE, Tozlovanu M, Naman F, Faid M, Pfohl-Leszkowicz A. 2006. Preminary data on the presence of mycotoxins (ochratoxin A, citrinin and aflatoxin B1) in black table olives "Greek style" of Moraccon origin. Mol. Nutr. Food Res. 50, 507-512.Altschul SF, Gish W, Miller W, Myers EW, Lipman DJ. 1990. Basic local alignment search tool. J. Mol. Biol., 215: 403-410.

Aran N. 2012. Gıda Biyoteknolojisi, Geliştirilmiş 2. Baskı, Nobel Yayınevi. İstanbul Teknik Üniversitesi. pp. 49.

Arroyo-López FN, Dura'n-Quintana MC, Ruiz-Barba JL, Querol A, Garrido-Fernandez A. 2006. Use of molecular methods for the identification of yeast associated with table olives. Food Microbiol. 23:791-796.

Baffi MA, Romo-Sanchez S, Ubeda-Iranzo J, Briones-Perez AI. 2012. Fungi isolated from olive ecosystems and screening of their potential biotechnological use. New Biotechnology. 29: 451-456.
Baskou D. 2015. Olive and olive oil bioactive contituents. Olive oil chemistry and technology, 2nd edition, AOCS press.

Carbone I, Kohn LM. 1999. A method for designing primer sets for speciation studies in filamentous ascomycetes. Mycologia, 91: 553-556.

Carlucci A, Ra1mondo ML, Cibelli F, Phillips AJL, Lops F. 2013. Pleurostomophora richardsiae, Neofusicoccum parvum and Phaeoacremonium aleophilum associated with a decline of olives in Southern Italy, Phytopathologia Mediterranea. 52(3): 517-527.

Chliyeh M, Rhimini Y, Selmaouil K, Touhamil AO, Filali-Maltouf A, El Modafar C, Moukhli, A, Oukabli, A, Benkirane R, Douira A. 2014. Survey of the fungal species associated to olive-tree (Olea europaea L.) in Morocco. Int. J. Rec. Biotech. 2: 15-32.

Ghitakou S, Koutras K, Kanellou E, Markaki. 2006. Study of aflatoxin B1 and ochratoxin A production by natural microflora and Aspergillus parasiticus in black and green olives of Greek origin. Food Microbiol 23: 612-621.

Glass NL, Donaldson GC. 1995. Development of primer sets designed for use with the PCR to amplify conserved genes from filamentous ascomycetes. Appl. Environ. Microb. Apr., 13231330.

Gonvances JS, Ferracin LM, Vieira MLC, Iamanaka BT, Taniwaki MH, Pelegrinelli Fungaro MH. 2012. Molecular analysis of Aspergillus section Flavi isolated from Brazil nuts. World J Microbiol Biotechnol. 28: 1817-1825.

Feng W, Zheng X. 2006. Control of Alternaria alternata by cassia oil in combination with potassium chloride or sodium chloride. Journal of Applied Microbiology. 101: 1317-1322.

Hall TA. 1999. Bioedit: A user-friendly biological sequence alignment editor and analysis program for Windows95/98/NT. Nucleic Acids Symposium Series. 41: 95-98.

Heperkan D, Meric BE, Sismanoglu G, Dalkılıç G, Güler FK. 2006. Mycobiota, mycotoxigenic fungi and citrinin production in black olives. Advances in Food Microbiology,571, 203-210.

Heperkan D. 2013. Microbiota of table olive fermentations and criteria of selection for their use as starters. Frontiers in Microbiology. 4: 1-11.

Hong SY, Oh JH, Lee I. 2011. Simultaneous enrichment of deglycosylated ginsenosides and monacolin $\mathrm{K}$ in red ginseng by fermentation with Monascus pilosus. Bioscience, biotechnology, and biochemistry. 75: 1490-1495.

Lumi Abe, C. A., Bertechini Faria, C., Fernandes de Castro, F., et al. 2015. Fungi Isolated from Maize (Zea mays L.) Grains and Production of Associated Enzyme Activities. International Journal of Molecular Sciences, 16(7): 15328-15346.

Magnani M, Fernandes T, Prete CEC, Homechim M, Ono EYS, Vilas-Boas LA, Satori D, Furlaneto MC, Fungaro MHP. 2005. Molecular identification of Aspergillus spp. isolated from coffee beans. Sci. Agric. (Piracicaba, Braz.). 62: 45-49.

Marsilio V, Campestre C, Lanza B, De Angelis M. 2001. "Sugar and polyol compositions of some European olive fruit varieties (Olea europaea L.) suitable or table olive purposes". Food Chem. 72: 485-490.

Oliveria I, Pereira JA, Lino-Neto T, Bento A, Baptista P. 2012. Fungal diversity associated to the olive moth, Prays Oleae bernard: A survey for potential entomopathogenic fungi. Microb Ecol. 63: 964-974.

Özkaya MT, Tunalığlu R, Eken Ş, Ulaş M, Tan M, Danacı A, İnan N, Tibet İ. 2010. "Türkiye zeytinciliğinin sorunları ve çözüm önerileri”. Türkiye Ziraat Mühendisliği V. Teknik Kongresi 1115 Ocak 2010.

Pereira AP, Ferreira ICFR, Marcelino F, Valentao P, Andrade PB, Seabra R, Estevinho L, Bento A, Pereira JA. 2007. Phenolic compounds and antimicrobial activity of olive (Olea europaea 1. cv. cobrançosa) leaves. Molecules. 12: 1153-1162.

Piccolo SL, Mondello V, Giambra S, Conigliaro G, Torta L, Burruano S. 2014. Arthrinium phaeospermum, Phoma cladoniicola and Ulocladium consortiale, New Olive Pathogens in Italy. J Phytopathol 162: 258-263. 
Roussos S, Zaouia N, Salih G, Tantaoui-Elaraki A, Lamrani K, Cheheb M, Hassouni H, Verhe F, Perraud-Gaime I, Augur C, Ismaili-Alaoui M. 2006. Characterization of filamentous fungi isolated from Moroccan olive and olive cake: Toxinogenic potential of Aspergillus strains. Molecular Nutrition \& Food Research. 50: 500-506.

Russel R, Peterson M. 2006. Identification and quantification of mycotoxigenic fungi by PCR. Process Biochemistry. 41: 14671474.

Su YC, Wang JJ, Lin TT, Pan TM. 2003. Production of the secondary metabolites c-aminobutyric acid and monacolin $\mathrm{K}$ by Monascus. J Ind Microbiol Biotechnol. 30: 41-46.

Şahin I, Korukoglu M. 2000. Küf-Gıda-İnsan, Uludağ Üniversitesi Güçlendirme Vakfi, Yayın No: 155, Bursa.

Şahin OI, Aka A, Akpınar-Bayizit A, Baltaş-Minas E. 2010. Sofralık zeytin üretim tesislerinde gıda güvenliği yönetim sisteminin uygulanması. U. Ü. Ziraat Fakültesi Dergisi, 24(1): $11-24$
Tokuşoğlu Ö, Alpas, H, Bozoğlu F. 2010. High hydrostatic pressure effects on mold flora, citrinin mycotoxin, hydroxytyrosol, oleuropein phenolics and antioxidant activity of black table olives. Innovative Food Science and Emerging Technologies. 11: $250-258$.

TUIK. 2016. http://www.tuik.gov.tr/PreTablo.do?alt_id=1001. Access date:28.06.2017.

TUIK. 2013. http://www.tuik.gov.tr/ilGostergeleri/iller/ CANAKKALE.pdf. Access date:28.06.2017.

Wang C, García-Fernández D, Mas A, Esteve-Zarzoso B. 2015. Fungal diversity in grape must and wine fermentation assessed by massive sequencing, quantitative PCR and DGGE. Frontiers in Microbiology, 6, 1156. 